Kelola

Jurnal Manajemen Pendidikan

Magister Manajemen Pendidikan

e-ISSN 2549-9661

FKIP Universitas Kristen Satya Wacana

Volume: 7, No. 1, Januari-Juni 2020

jurnalkelola@gmail.com

Halaman: 98-109

\title{
Evaluasi Tempat Uji Kompetensi Teknisi Otomotif dalam Peningkatan Mutu Lulusan Sekolah Menengah Kejuruan
}

\author{
Sartono Manto Suwarno \\ Magister Manajemen Pendidikan Universitas Kristen Satya Wacana \\ sartono009@gmail.com \\ Bambang Ismanto \\ Magister Manajemen Pendidikan Universitas Kristen Satya Wacana \\ bambang.ismanto@uksw.edu
}

\begin{abstract}
The objective of this research is to evaluate the context, input, process and product components in Evaluating Implementation of Competency Test Place for Automotive Technician at SMK Negeri 2 Salatiga. The implementation of this research is conducted with a descriptive evaluative research method using CIPP (context, input, process and product) evaluation model. Data collection in this research is carried out through interviews, observations and documentations which are validated through Focus Group Discussion (FGD) activities. The results of this research stated that: 1). Context Evaluation of Implementation Competency Test Place for Automotive Technician at SMK Negeri 2 Salatiga is based on the identification of needs and policies by the government; 2). Input Evaluation of Implementation Competency Test Place for Automotive Technician at SMK Negeri 2 Salatiga already has technical and administrative readiness in the Field of Automotive Engineering Expertise; and Competency Test for Automotive Technicians; 3). Process Evaluation of Implementation Competency Test Place for Automotive Technician is still not in accordance with expectations and plans that have been made; 4). Product Evaluation of Implementation Competency Test Place for Automotive Technician at SMK Negeri 2 Salatiga has been carried out, however there are still many obstacles encountered in it. The conclusion of this research is the decision on the Implementation Competency Test Place for Automotive Technician at SMK Negeri 2 Salatiga is more incremental. It seems to be an important consideration that the Implementation Competency Test Place for Automotive Technician at SMK Negeri 2 Salatiga should be continued with some improvements.
\end{abstract}

Keywords: Competency Test Place, Program Evaluation, CIPP Model

\section{Article Info}

Received date: 9 Januari $2020 \quad$ Revised date: 29 Juni $2020 \quad$ Accepted date: 29 Juni 2020

\section{PENDAHULUAN}

Sekolah Menengah Kejuruan (SMK) dikembangkan untuk menyiapkan tenaga operasional yang memiliki keterampilan sesuai kebutuhan di dunia usaha / industry. Kurikulum dirancang dalam pengembangkan kompetensi inti dan dasar sikap spiritual; sikap 98 sosial; pengetahuan; dan keterampilan (Permendikbud Nomor 60 Tahun 2014 Tentang Kurikulum 2013 SMK/MAK). Pengembangan sikap, pengetahuan dan keterampilan para siswa SMK dilakukan melalui pembelajaran teori, praktek 
laboratotirum dan bengkel serta praktek kerja industry.

Pengukuran tingkat kompetensi lulusan SMK perlu dilakukan untuk mengetahui kesiapan memasuki lingkungan kerja sesuai bidang kejuruannya. Salah satu tolok ukur keberhasilan dalam peningkatan kualitas sumber daya manusia, yang dilakukan melalui pendidikan menengah kejuruan adalah pencapaian kompetensi yang sesuai dengan standar kompetensi kerja yang dipersyaratkan. Guna mewujudkan persyaratan tersebut, maka diperlukan Standar Kompetensi Kerja Nasional Indonesia sebagai acuan bagi penyelenggaraan pendidikan dan pelatihan serta uji kompetensi dalam rangka sertifikasi kompetensi pada sektor / bidang keahlian tertentu. Dasar hukum dalam rangka meningkatkan kompetensi kerja bagi para tenaga kerja terdapat dalam Undang Undang No. 13 Tahun 2003 Pasal 18 tentang Ketenagakerjaan bahwa "Setiap tenaga kerja berhak untuk memperoleh dan /atau meningkatkan dan /atau mengembangkan kompetensi kerja sesuai dengan bakat, minat dan kemampuannya melalui pelatihan kerja"..

Adanya kebebasan dan pemberian hak kepada setiap tenaga kerja untuk meningkatkan kompetensi yang dimiliki sesuai dengan kemampuan masing-masing. Dalam Peraturan Pemerintah No 23 Tahun 2004 Tentang Badan Nasional Sertifikasi Profesi Pasal 3, bahwa "BNSP dapat memberikan lisensi kepada Lembaga Sertifikasi Profesi yang memenuhi persyaratan". Lebih lanjutdisampaikan bahwa lisensi tersebut diberikan gunaterlaksananya tugas sertifikasi kompetensi yang ditetapkan, untuk melaksanakan sertifikasi kompetensi. Wewenang terhadap penyelenggaraan program uji kompetensi salah satunya diberikan kepada penyelenggara pendidikan dan lembaga pelatihan kepada peserta didik dan warga masyarakat yang membutuhkan sebagai pengakuan terhadap kompetensi. Sekolah Menengah Kejuruan (SMK) selaku penyelenggara pendidikan mempunyai potensi untuk dijadikan sebagai Tempat Uji Kompetensi (TUK) karena memiliki sarana prasarana untuk TUK yang memenuhi syarat. Selain itu SMK telah memperoleh kepercayaan dari masyarakat dan pemerintah dalam menyelenggarakan kegiatan pendidikan dan pelatihan.

Penyelenggaraan Tempat Uji Kompetensi di SMK Negeri 2 Salatiga, harapannya adalah dapat memberikan pelayanan terhadap masyarakat, alumni maupun peserta didik di SMK Negeri 2 Salatiga untuk dapat meningkatkan kompetensi dan mendapat pengakuan kompetensinya. Oleh karena itu, guna mengetahui sejauh mana kesenjangan penyelenggaraan program Tempat Uji Kompetensi tersebut, maka dilakukan penelitian dengan judul Evaluasi Tempat Uji Kompetensi Teknisi Otomotif di SMK Negeri 2 Salatiga, untuk mengevaluasi Context, Input, Process, Product terhadap penyelenggaraan Tempat Uji Kompetensi Teknisi Otomotif di SMK Negeri 2 Salatiga.

Penyelenggaraan program unit produksi dan jasa di SMK Negeri 2 Salatiga yang telah berdiri sejak tahun 2010 telah menghasilkan beberapa hasil produksi dan pemberian layanan jasa kepada DU/DI serta masyarakat (Sujoko, Bambang Ismanto :2017). Evaluasi Tempat Uji Kompetensi akan memberikan informasi tingkat pencapaian program-program yang direncanakan.

Menurut Rose \& Nyre (1977: 34) evaluasi merupakan sebuah proses yang dilakukan oleh sekelompok ahli yang profesional terhadap suatu program guna menentukan tindakan berikutnya. Sedangkan Stufflebeam dan Anthony J. Shinkfield (1985) secara singkat merumuskan evaluasi sebagai sistem penilaian tentang suatu harga atau jasa beberapa objek. Pendapat Stufflebeam tersebut, memberikan suatu gambaran pemahaman bahwa evaluasi sebagai sebuah sistem penilaian. Miller didalam Sukiman (2012 : 3), evaluasi diartikan sebagai "a qualitative 
judgment that uses measurement results from test and assessment information to assign grades". (suatu pertimbangan kualitatif yang menggunakan hasil pengukuran lewat informasi tes dan asesmen untuk menentukan kualitas. Dari pendapat yang telah diuraikan, dapat disimpulkan bahwa evaluasi merupakan suatu kegiatan mengumpulkan informasi tentang suatu program yang mempunyai tujuan untuk mengetahui sampai sejauh mana pelaksanaan program berjalan dan sejauh mana tujuan program tersebut tercapai. Arikunto (2009: 23) Evaluasi program adalah suatu rangkaian kegiatan yang dilakukan dengan sengaja untuk melihat tingkat keberhasilan program. Ada beberapa pengertian "program" itu sendiri. Di dalam kamus tertulis program adalah rencana, dan ada pula yang menulis bahwa program adalah kegiatan yang direncanakan dengan seksama. Sehingga evaluasi program adalah kegiatan yang dimaksud untuk mengetahui seberapa tinggi tingkat keberhasilan dari kegiatan yang direncanakan.

Mmperhatikan pendapat beberapa ahli diatas tentang definisi evaluasi, maka konsep evaluasi dipahami sebagai sebuah proses pengumpulan data (Tyler, 1950; Nyere \& Rose, 1977); sistem penilaian Stufflebeam\& A.J. Shinkfield (1985); pengukuran (Miller, 2012); suatu rangkaian kegiatan (Arikunto, 2009). Berdasarkan uraian tentang definisi evaluasi, maka dapat disimpulkan bahwa evaluasi merupakan suatu kegiatan mengumpulkan informasi atau data, guna mengukur ketercapaian suatu program dan mengambil langkah kebijakan berikutnya terhadap penyelenggaraan suatu program. Terdapat beberapa model evaluasi yang dapat digunakan dalam melakukan kegiatan evaluasi terhadap suatu program (Arikunto, 2010: 52) sebagai berikut: (1)Goal Oriented Evaluation Model, Fokus dari model evaluasi ini adalah tujuan dari program yang sudah ditetapkan jauh sebelumnya, pelaksanaan evaluasi dilakukan secara berkesinambungan, terus-menerus dan menge-cek sejauh mana program telah terlaksana. (2)Goal Free Evaluation Model. Model evaluasi ini tidak memperhatikan apa yang menjadi tujuan program, sehingga fokus dari model ini adalah melihat kinerja program dan hal-hal yang terjadi baik positif maupun negatif dalam pelaksanaan program. (3)Formatif-Sumatif Evaluation Model. Merupakan model evaluasi yang menunjuk adanya tahapan dan lingkungan obyek yang dievaluasi. Model evaluasi ini dilakukan ketika program masih berjalan (Formatif) dan ketika program sudah selesai (Sumatif). (CSE-UCLA Evaluation Model Center for the Study of Evaluation University of California in Los Angeles. Dalam pelaksanaan model evaluasi ini, meliputi empat tahapan yakni 1). Needs Assessment, 2). Program Planning, 3). Formative Evaluation, 4). Sumative Evaluation. (4)CIPP Evaluation Model. Model evaluasi ini dikembangkan oleh Stufflebeam dkk pada tahun 1967. Model evaluasi CIPP melakukan tindakan evaluasi yang mencakup empat sasaran evaluasi yakni konteks, input, proses dan produk.(5)Descrepancy Evaluation Model. Model ini dikembangkan oleh Malcon Provus, substansi dalam evaluasi model ini mencakup pada design, instalation, process, product, cost and benefit analysis.

Pemahaman mengenai konsep uji kompetensi tidak bisa terlepas dari pemahaman tentang kompetensi itu sendiri. Sedangkan Kompetensi dimaknai sebagai sebuah kemampuan, kekuasaan, kewenangan dan keterampilan yang dimiliki seseorang untuk melakukan suatu tugas tertentu (Ghozali, 2004: 65). Melalui definisi diatas memberikan suatu pemahaman bahwa kompetensi dimaknai sebagai sebuah skill atau kemampuan yang dimiliki oleh seseorang. Kompetensi juga dipahami sebagai perpaduan dari pengetahuan, keterampilan, nilai dan sikap yang direfleksikan dalam kebiasaan berfikir dan bertindak (Mulyasa, 2004: 38). 
Merujuk pada pendapat beberapa tokoh diatas, maka dapat dikutip beberapa point penting bahwa kompetensi merupakan sebuah keterampilan, kemampuan, kekuasaan, kewenangan serta aspek sikap dan nilai yang dimiliki oleh seseorang (Ghozali, 2004; Mulyasa, 2004). Dengan demikian dapat disimpulkan bahwa kompetensi merupakan suatu keterampilan atau kemampuan yang dimiliki seseorang baik berupa kemampuan kognitif, afektif maupun psikomotor.

Uji kompetensi juga dimaknai sebagai sebuah penilaian mengenai kemampuan atau kompetensi seseorang terhadap suatu bidang keahlian. Secara khusus bahwa pelaksanaan uji kompetensi dilakukan oleh penguji atau asesor uji kompetensi untuk mengukur tingkat pencapaian kompetensi hasil belajar peserta didik, perserta kursus dan satuan pendidikan nonformal lainnya, serta warga masyarakat yang belajar mandiri pada suatu jenis dan tingkat pendidikan tertentu (Departemen Pendidikan Nasional, 2009). Uji kompetensi juga dimaksudkan untuk menilai keterampilan kerja yang dimilik oleh seseorang. Lebih lanjut ditekankan bahwa melalu uji kompetensi maka indikator-indikator kompetensi yang dimiliki seseorang akan dapat terpenuhi dan dikembangkan lebih lanjut, (UNESCO, 2003). Sertifikat kompetensi diberikan penyelenggara pendidikan dan lembaga pelatihan kepada peserta didik dan warga masyarakat sebagai pengakuan terhadap kompetensi untuk pekerjaan tertentu setelah lulus uji kompetensi yang diselenggarakan oleh satuan pendidikan yang telah terakreditasi (UU No. 20 Tahun 2003 Tentang Sisdiknas). Penelitian yang relevan sebelumnya terkait dengan kegiatan evaluasi terhadap Tempat Uji Kompetensi dilakukan oleh Nuryake (2012) dengan judul Evaluasi Pelaksanaan TeachingFactory SMK di Surakarta, menyatakan bahwa pelaksanaan Teaching Factory SMK di Surakarta dari segi pembelajaran dan pelatihan berjalan sangatbaik, hal tersebut dikarenakan bahwa proses pembelajaran praktik dilaksanakan sesuai dengan prosedur kerja yang sesungguhnya. Secara garis besar bahwa uraian hasil penelitian diatas, memberikan sebuah gambaran bahwa untuk mewujudkan pelaksanaan tempat uji kompetensi maka perlunya pelaksanaan Standart Operational Procedure (SOP) dengan benar.

Penelitian yang dilakukan oleh Sudjarwo (2008) dengan judul Evaluasi Kinerja Penyelenggaraan Pendidikan dan Pelatihan Kepemimpinan Tingkat IV Pada Balai Diklat Keagamaan Semarang. Hasil penelitian tersebut menunjukkan bahwa status kinerja input kurang, status kinerja proses baik sedang status kinerja output sedang. Uraian dari hasil penelitian Sudjarwo memberikan sebuah deskripsi bahwa dari segi proses penyelenggaraan masuk dalam kategori baik. Berdasarkan kedua uraian hasil penelitian yang dilakukan oleh Nuryake dan Sudjawo diatas, memberikan satu gambaran substansi bahwa penyelenggaraan suatu tempat pelatihan maupun uji kompetensi perlu dilakukan dengan baik dan sesuai dengan prosedur yang sebenarnya. Hasil penelitian relevan terkait dengan evaluasi uji kompetensi juga dilakukan oleh Irwanti dan Sudira (2014) dengan judul Evaluasi Uji Kompetensi Siswa Keahlian Multimedia di SMK Se Kota Yogyakarta. Adapun hasil penelitian tersebut menunjukkan bahwa ditinjau dari aspek 1). context masuk dalam kategori sangat sesuai, 2). Aspek input masuk dalam kategori sangat sesuai, 3). Aspek process masuk dalam kategori sangat baik 4). Aspek product masuk dalam kategori sangat baik. Lebih lanjut dinyatakan bahwa dari segi aspek input bahwa kelayakan tempat uji kompetensi dan kelengkapan sarana dan prasarana menjadiindikator yang sangat sesuai terhadap penyelenggaraan uji kompetensi tersebut. Penilaian dari perspektif yang berbeda ditunjukkan dalam hasil penelitian Nuryake terfokus pada pelaksanaan Standar Opetional Procedure penyelenggaraan program uji 
kompetensi, sedangkan hasil penelitian Sudjarwo menitik beratkan pada substansi penyelenggaraan program khususnya pelaksanaan yang sesuai prosedur. Sedangkan hasil penelitian Sudira dan Irwanti lebih menekankan pada kualitas sarana dan prasarana. Berbeda dengan hasil penelitian diatas, hasil penelitian terkait dengan evaluasi tempat uji kompetensi juga dilakukan oleh I Nyoman, dkk (2014) Evaluasi Manajemen TeachingFactory Pada Unit Produksi Training Hotel SMK Kridawisata. Penelitian bertujuanmengevaluasi pengelolaan Teaching Factory Pada Unit Produksi Jurusan Perhotelan SMK Kridawisata Bandar Lampung. Kualitas kegiatan teaching factory mampu menciptakan budaya industri di sekolah dan menjadi salah satu sumber pendanaan untuk sekolah. Hasil penelitian ini secara tidak langsung menunjukkan bahwa pengelolaan Teaching Factory Pada Unit Produksi Training Hotel SMK Kridawisata, masih belum sesuai dengan apa yang diharapkan dengan tujuan yang telah dirancang.

Hasil penelitian lain terkait dengan evaluasi tempat uji kompetensi juga dilakukan oleh Pan Wei Rong (2009) Analysis of Teaching Factory Model of NanyangPolytechnic. Hasil penelitian ini menunjukkan bahwa dalam pengelolaan Teaching Factory Nanyang Polytechnic telah mengintegrasikan teori kedalam praktek, serta mampumengintegrasikan materi pengajaran sesuai dengan kebutuhan dunia industri. Secara umum bahwa hasil penelitian ini lebih menekankan pada relevansi pengajaran Teaching Factory sesuai dengan kebutuhan dunia Industri. Penelitian Teaching Factory Nanyang Polytechnic telah menunjukkan bahwa pengelolaan Teaching Factory telah dilakukan secara baik. Hasil penelitian yang relevan juga dilakukan oleh Mao Cai Sheng (2009) Educational Feature of Singapore's Teaching Factoryand Its Implication. Penelitian ini bertujuan untuk mengukur sejauh mana implikasipengelolaan Teaching Factory mampu menjadi basis produksi dan praktek yang baik bagi perusahaan. Hasil penelitian ini menunjukkan bahwa dalam pengelolaan Teaching Factory telah mampu dilaksanakan dengan baik.

\section{METODE PENELITIAN}

Penelitian ini merupakan penelitian evaluatif deskriptif dengan model evaluasi Context, Input, Process, Product (CIPP) Hal tersebut dikarenakan bahwa dalam penelitian ini berupaya melakukankegiatan evaluasi dan memberikan gambaran mengenai data penelitian yang berupa keterangan, pernyataan serta kebijakan mengenai penyelenggaraan Tempat Uji Kompetensi Teknisi Otomotif di SMK Negeri 2 Salatiga. Penelitian dilakukan di SMK Negeri 2 Salatiga Yang beralamat di Jl. Parikesit Kelurahan Dukuh, Kecamatan Sidomukti Salatiga, pada Tempat Uji Kompetensi Bidang Keahlian Otomotif. Sedangkan waktu pelaksanaan pada penelitian ini adalah tahun 2016/2017. Dalam penelitian evaluasi ini, teknik yang digunakan untuk mengumpulkan informasi data penelitian meliputi kegiatan wawancara, observasi, studi dokumentasi serta menggunakan Focus Group Discussion (FGD) sebagai validasi data dalam penelitian ini. Kegiatan teknik analisis data dalam penelitian ini meliputi beberapa hal sebagai berikut 1). Koleksi data, 2). Reduksi Data, 3). Display Data, 4). Verifikasi/ Kesimpulan data (Miles and Huberman dalam Sugiyono, 2013). Tahapan koleksi data, dilakukan pengumpulkan data yang diperoleh dari sumber yang diperoleh baik melalui wawancara, observasi maupun studi dokumentasi. Berikutnya setelah data terkumpul, dilakukan penyederhanaan, transformasi dan penggolongan data yang telah terkumpul. Data direduksi sesuai berdasarkan pada komponen model evaluasi CIPP meliputi komponen context, imput, process dan product. 
Setelah data direduksi dan digolongkan sesuai dengan model evaluasi CIPP, tahap berikutnya adalah penyajian data yang telah digolongkan berdasarkan pada model evaluasi CIPP agar lebih mudah dipahami dan sebih terstruktur untuk dipahami. Tahapan terakhir dalam teknis analis data yakni dilakukan proses penarikan kesimpulan atau verifikasi. Validitas data yang digunakan dalam penelitian ini menggunakan teknik triangulasi sumber. Dalam penelitian ini, triangulasi sumber dilakukan dengan cara memvalidasi data yang diperoleh dengan teknik wawancara, observasi dan studi dokumentasi melalui kegiatan Focus Group Discussion. Adapun melalui kegiatan $F G D$ nanti akan diperoleh data hasilpenelitian yang telah tervalidasi sebagai bahan untuk melakukan pembahasan dalam kegiatan penelitian evaluasi, melalui hasil diskusi yang menghadirkan narasumber meliputi Kepala Sekolah, Wakil Kepala Sekolah Bidang Hubungan Masyarakat dan industri , Ketua TUK Teknisi Otomotif, Ketua Program Bidang Keahlian Teknik Otomotif, tenaga teknis, guru, tenaga administrasi, Industri pengguna jasa/pelanggan, alumni.

\section{HASIL PENELITIAN DAN \\ PEMBAHASAN \\ Hasil Penelitian \\ Aspek Context}

Program Tempat Uji Kompetensi (TUK) Teknik Otomotif di SMK Negeri 2 Salatiga dikelola manajemen Sekolah sesuai Pedoman / Petunjuk teknis yang ditetapkan. Penyelenggaraan Program Tempat Uji Kompetensi Teknik Otomotif di SMK Negeri 2 Salatiga telah merujuk pada Undang-Undang Nomor 20 Tahuun 2003 Tentang Sistem Pendidikan Nasional, Undang-Undang Nomor 13 Tahun 2003 Tentang Ketenagakerjaan, Peraturan Pemerintah No. 23 Tahun 2004 Tentang Badan Nasional Sertifikasi Profesi. Sedangkan petunjuk teknis pada Program
Tempat Uji Kompetensi di SMK Negeri 2 Salatiga mengacu pada Pedoman BNSP No 206 Tahun 2007. Kebijakan pengembangan kegiatan TUK memperhatikan masukanmasukan dari dunia usaha / industri, masyarakat dan Dinas Pendidikan Provinsi Jawa Tengah. Wawancara dengan Tempat magang Praktek kerja Industri memberikan masukan agar SMK Negeri 2 Salatiga untuk memperhatikan ketercapaian tujuan, sasaran dan target yang ditetapkan. Perkembangan dunia otomotif menjadi pertimbangan pengelola dalam menyusun perencanaan program TUK. Para guru pembimbing selalu memberikan masukan berdasarkan pengalaman mendampingi peserta didik dalam Praktek Kerja Industri (PRAKERIN).

\section{Aspek Input}

Dasar hukum penyelenggaraan Program Tempat Uji Kompetensi di SMK Negeri 2 Salatiga berdasarkan pada Surat Keputusan Lembaga Sertifikasi Profesi Teknik Otomotif Nomor: Kep-031/SK LSPTO/Re.TUK/JKT/III/2011 sebagai Tempat Uji Kompetensi dengan level Madya/Senior. Pengelolan Program Tempat Uji Kompetensi di SMK Negeri 2 telah dibentuk berdasarkan pada kebutuhan. Hal tersebut juga didukung oleh Surat Keputusan 001/A-2/Mar/2016/Bid.Mutu, hal 16-18 tentang struktur organisasi penyelenggaraan Tempat Uji Kompetensi Teknik Otomotif di SMK NEGERI 2 Salatiga. Mekanisme pelaksanaan Tempat Program Tempat Uji Kompetensi Teknik Otomotif SMK Negeri 2 Salatiga dilakukan dengan mengacu pada penerapan sistem manajemen mutu pedoman BNSP 206/ISO 17024. Berdasarkan pada pedomantersebut, terdapat ruang lingkup assesment dalam uji kompetensi pada program yang akan di ujikan. Ruang lingkup assesment dalam pelaksanaan Uji Kompetensi Teknik Otomotif dapat dilihat melalui tabel 1 sebagai berikut: 
Tabel 1. Ruang Lingkup Assesment dalam PelaksanaanUji Kompetensi Teknik Otomotif

\begin{tabular}{c|l|c|l}
\hline No & \multicolumn{1}{|c|}{ Ruang Lingkup Asesmen } & Bid. Pekerjaan & \multicolumn{1}{c}{ Level/ Kualifikasi } \\
\hline 1 & Klaster Engine Tune Up Konvensional & Teknisi Otomotif & Engine Tune Up Konvensional \\
\hline 2 & Klaster Engine Tune Up Sistem Injeksi & Teknisi Otomotif & Engine Tune Up Sistem Injeksi \\
\hline 3 & Klaster Emisi Gas Buang & Teknisi Otomotif & Emisi Gas Buang \\
\hline 4 & Klaster Sistem Rem Manual & Teknisi Otomotif & Sistem Rem Manual \\
\hline 5 & Klaster Wheel Alignment & Teknisi Otomotif & Wheel Alignment Spooring \& Balancing \\
\hline
\end{tabular}

Sumber: Panduan Mutu TUK TO SMK Negeri 2 Salatiga, 2016

Daya dukung dalam penyelenggaraan Program Tempat Uji Kompetensi Teknik Otomotif di SMK Negeri 2 Salatiga, tidak terlepas dari sumber daya manusia meliputi : instruktur, /tenaga pengajar pada Program Tempat Uji Kompetensi dapat dilihat pada tabel 2 sebagai berikut:

Tabel 2. Kualifikasi Instruktur Program TUK Teknik Otomotif SMK Negeri 2 Salatiga

\begin{tabular}{c|c|c|c|c|l}
\hline \multirow{2}{*}{ No. } & \multicolumn{2}{|c|}{ Kualifikasi Pendidikan } & \multirow{2}{*}{ Jumlah } & \multicolumn{1}{|}{ Bidang Keahlian } \\
\cline { 2 - 4 } & D3 & S1 & S2 & & \\
\hline 1 & - & 9 & 1 & 4 & Engine Tune Up Konvensional \\
\hline 2 & - & 2 & - & 2 & Engine Tune Up Sistem Injeksi \\
\hline 3 & & 3 & - & 3 & Emisi Gas Buang \\
\hline 4 & - & 1 & 1 & 2 & Sistem Rem Manual \\
\hline 5 & - & 3 & - & 3 & Wheel Alignment (WA)/Spooring \& Balancing \\
\hline & & & & 14 & \\
\hline
\end{tabular}

Sumber: Data Sekretaris TUK TO SMK Negeri 2 Salatiga, 2016

Sedangkan pada aspek sumber daya manusia dari segi peserta Uji Kompetensi Teknik Otomotif, dapat berasal dari Institusi Pendidikan, baik guru maupun peserta didik, masyarakat umum dan peserta dari Dunia Usaha dan Industri.Pembiayaan dalam penyelenggaraan Program Tempat Uji Kompetensi Teknik Otomotif di SMK Negeri 2 Salatiga, bersumber dari dana Pemerintah Pusat, Pemerintah Daerah dan peserta Uji Kompetensi. Pembiayaan digunakan untuk perawatan sarana dan prasarana, operasional program yang mencakup pembelian ATK, administrasi, honor instruktur pengajar dan biaya penerbitan sertifikat uji kompetensi dari BNSP (Badan Nasional Sertifikasi Profesi).

Program Tempat Uji Kompetensi Teknik Otomotif di SMK Negeri 2 Salatiga, telah memiliki beberapa fasilitas sarana dan prasaran pendukung penyelenggaraan program , yang dapat dilihat melalui tabel 3 sebagai berikut:

Tabel 3. Data Sarpras TUK TO SMK Negeri 2 Salatiga

\begin{tabular}{l|l|l|c|c}
\hline No & \multicolumn{1}{|c|}{ Uraian } & \multicolumn{1}{|c}{ Spesifikasi } & Jumlah & Satuan \\
\hline 1 & Mobil FR & Xenia Xi A/T 1,3 VVTi & 1 & Unit \\
\hline 2 & Mobil FR & Avanza 1.5 S M/T VVTi & 2 & Unit \\
\hline 3 & Scanner Mobil VG & Asian, Europe vehicle & 3 & Unit \\
\hline 4 & Gas Analyzer & Asian, Europe Gasoline Engine & 2 & Unit \\
\hline 5 & V JACK & Hesbon 2000 Kg & 1 & Paket \\
\hline 6 & Transmission JACK & 500 Kg & 1 & Unit \\
\hline 7 & Car Wash Equipment & Two Post Lift & 1 & Paket \\
\hline 8 & Komputer for training & Laptop Intel Core i5 & 2 & Unit \\
\hline 9 & Ruang Kelas & Kapasitas 50 orang & 4 & Unit \\
\hline 10 & Ruang Praktek & Praktek Peserta & 2 & Unit \\
\hline 11 & Caddy and tool set & Standart mekanik & & set \\
\hline Sumber: Data Sekretaris $T U K T O, 2017$ &
\end{tabular}


Aspek Process

Upaya-upaya yang terus dilakukan oleh pihak penyelenggaran Tempat Uji Kompetensi SMK Negeri 2 Salatiga dalam peningkatan kompetensi instruktur melalui berbagai pelatihan. Kegiatan Diklat instruktur Tempat Uji Kompetensi di SMK Negeri 2 Salatiga dapat dilihat pada tabel 4 sebagai berikut:

Tabel 4. TentangKegiatan Pelatihan Instruktur TUK SMK Negeri 2 Salatiga

\begin{tabular}{l|l|l|l}
\hline No & \multicolumn{1}{|c|}{ Kegiatan } & \multicolumn{1}{c}{ Uraian } & \multicolumn{1}{c}{ Waktu } \\
\hline 1 & Diklat di Industri Otomotif & Industri Otomotif oleh PT. Astra Daihatsu Jakarta & Maret 2011 \\
\hline 2 & IHT Guru Otomotif & Penguatan Otomotif Dasar & Mei 2011 \\
\hline 3 & IHT Guru Otomotif & Penguatan Otomotif Advance & September 2011 \\
\hline 4 & Diklat Instruktur Mandiri & Pro Technician Internasional di PT. Astra Daihatsu Motor & September 2011 \\
\hline 5 & IHT Guru Otomotif & Kurikulum Advance Otomotif & Oktober 2011 \\
\hline 6 & Diklat Assesor Mandiri & Metodologi Assesor BNSP/ LSP Otomotif (LSP TO) & November 2011 \\
\hline 7 & Diklat dan UKG & Engine Tune Up EFI & November 2011 \\
\hline
\end{tabular}

Sumber: Sekretaris TUK TO SMK Negeri 2 Salatiga, 2017

Implementasi dalam penyelenggaraan pada Tempat Uji Kompetensi Teknik Otomotif, dilihat dari segi pendanaan tidak mengalami kendala yang cukup berarti dengan adanya bantuan subsidi dana baik dari pemerintah pusat maupun daerah. Dilihat dari segi pelaksanaan kegiatan, penyelenggaraan Tempat Uji Kompetensi Teknik Otomotif masih belum berjalan sesuai dengan apa yang diharapkan.Rendahnya minat tenaga kerja atau masyarakat untuk mengikuti uji kompetensi menjadi salah satu indikator kurang tercapainya penyelenggaraan Tempat Uji Kompetensi Teknik Otomotif, bahkan belum adanya kepastian untuk memperoleh peserta yang berminat mengikuti program tersebut menjadi sebuah temuan yang sangat menarik dalam penelitian ini. Bahwa tidak adanya pengakuan dari Dunia Usaha dan Dunia Industri, terhadap sertifikat profesi yang dimilik pasca mengikuti uji kompetensi keahlian juga menjadi permasalahan bagi Program Tempat Uji Kompetensi Teknik Otomotif.

\section{Aspek Product}

Dalam rangka mengukur kompetensi yang dimiliki peserta uji kompetensi, terdapat empat standar baku dari masing-masing klaster bidang keahlian. Pada bidang keahlian Engine Tune Up Konvensional telah memiliki pedoman skema sertifikasi dengan nomor skema sertifikasi 1/V/SKM/15, bidang keahlian Service Chasis telah memiliki pedoman skema sertifikasi dengan nomor skema sertifikasi 2/V/SKM/15, pada bidang Pemeliharaan Sistem Elektrikal telah memiliki pedoman skema sertifikasi dengan nomor skema sertifikasi 3/V/SKM.15, dan terakhir pada bidang Engine Tune Up Sistem Injeksi telah memiliki pedoman skema sertifikasi dengan nomor skema sertifikasi 4/V/SKM/15. Keempat skema sertifikasi diatas merupakan standar baku yang dikeluarkan oleh Lembaga Sertifikasi Profesi (LSP), dalam rangka mengukur kompetensi bagi para peserta uji kompetensi. Selain menggunakan skema sertifikasi yang disusun oleh LSP, penentuan kelulusan seorang peserta uji kompetensi juga dinyatakan pada kriteria yang telah tercantum dalam skema setifikasi pada tempat uji kompetensi. Kriteria kelulusan tersebut meliputi: Kompeten (K);Belum Kompeten (BK); dan Penilaian lanjut (PL).

\section{Pembahasan}

Program Tempat Uji Kompetensi Teknik Otomotif SMK Negeri 2 Salatiga, didukung dengan kebijakan program, sumber daya manusia, sarana dan prasarana yang cukup memadahi,apabila dilihat pada aspek Input telah sesuai dengan analisis kebutuhan baik masyarakat maupun dunia industri.(BNSP, 2007: 40) bahwa tempat kerja dan atau lembaga yang dapat memberikan fasilitas pelaksanaan uji kompetensi, yang telah diverifikasi oleh Lembaga Sertifikasi Profesi (LSP) berlisensi, 
diharapkan mampu memberikan layanan fasilitas kepada masyarakat. Senada dengan hasil penelitian Irwanti dan Sudira (2014) tentang Evaluasi Uji Kompetensi Siswa Keahlian Multimedia di SMK Se Kota Yogyakarta yang menyatakan bahwa evaluasi pada aspek Input sangat sesuai dengan kebutuhan. Hasil penelitian Pan Wei Rong (2009) tentang Analysis of Teaching Factory Model of Nanyang Polytechnicdan Mao Cai Sheng (2009) tentang Educational Feature of Singapore's Teaching Factory and Its Implication bahwa melalui adanya Teaching Factory akan mampu menjadikan wadah sebagai pengembangan dan pembelajaran siswa sebelum memasuki dunia industri. Berdasarkan pada hasil temuan dan penelitian relevan, maka dapat ditarik kesimpulan bahwa evaluasi Context pada Program Tempat Uji Kompetensi Teknik Otomotif sangat sesuai dengan identifikasi kebutuhan dalam menyelenggarakan program.

Dalam tahapan input penyelenggaraan Program Tempat Uji Kompetensi Teknik Otomotif, SMK Negeri 2 Salatiga berupaya menyelenggarakan tempat uji kompetensi sesuai dengan kebutuhan tempat kerja dan standar pemerintah. Direktorat SMK Tahun 2007 yang menyatakan bahwa penyelenggaraan Tempat Uji Kompetensi harus dipertimbangkan dan disesuaikan akan kebutuhan dunia industri serta mengacu pada standar operasional penyelenggaraan.

Program Tempat Uji Kompetensi Teknik Otomotif di SMK Negeri 2 Salatiga, telah memperoleh ijin berdasarkan pada Surat Keputusan Lembaga Sertifikasi Profesi Teknik Otomotif Nomor: Kep-031/SK LSPTO/Re.TUK/JKT/III/2011. Temuan hasil penelitian tersebut, nampaknya diperkuat oleh pendapat Pidarta (2004: 26) bahwa tahapan dalam perencanaan merupakan bagian dari langkah peningkatan mutu terhadap perbaikan program. Hal tersebut juga diperkuat oleh Standar Operational Procedure (SOP) berupa 106 pedoman BNSP 206/ISO 17024 terkait dengan mekanisme kerja Program Tempat Uji Kompetensi Teknik Otomotif di SMK Negeri 2 Salatiga.

Pentingnya penerapan Standar

Operational Procedure (SOP) terhadap mekanisme kerja Tempat Uji Kompetensi Teknik Otomotif, menjadi komponen penting dalam penyelenggaraan program. Hal tersebut juga selaras dengan hasil penelitian Nuryake (2012) bahwa pelaksanaan Standart Operational Procedure (SOP) dengan benar, menjadi point penting dalam penyelenggaraan sebuah program. Evaluasi process dalam penyelenggaraan pada Program Tempat Uji Kompetensi Teknik Otomotif, ditunjukkan melalui kompetensi instruktur pengajar dan pelaksanaan dari kegiatan uji kompetensi tersebut. Berdasarkan hasil temuan penelitian, bahwa dari segi pendidikan akademik para instruktur yang dimiliki oleh Tempat Uji Kompetensi Teknik Otomotif memiliki kualifikasi pendidikan S1 dan S2. Selain itu, para instruktur telah didukung dengan modelmodel pelatihan peningkatan kompetensi baik berupa IHT maupun diklat mandiri. Pendapat Pidarta (2004:28) bahwa manajemen pendidikan berupaya untuk memadukan seluruh aktivitas sumber-sumber pendidikan agar terpusat dalam upaya mencapai tujuan pendidikan.

Merujuk dari ulasan temuan penelitian tersebut, dapat dipahami bahwa dunia industri memiliki kriteria tersendiri dalam menilai kompetensi yang dimiliki oleh seorang tenaga kerja. Berdasarkan pada uraian hasil penelitian, dapat disimpulkan bahwa evaluasi proses program Tempat Uji Kompetensi Teknik Otomotif di SMK Negeri 2 Salatiga masih belum sesuai dengan harapan yang telah dirancang oleh pengelola.

Evaluasi aspek produk dalam penyelenggaraan Program Tempat Uji Kompetensi Teknik Otomotif di SMK Negeri 2 Salatiga, bahwa penyelenggaraan program ini 
masih belum tercapai sesuai dengan apa yang diharapkan, kendala yang dihadapi ialah jumlah peminat untuk mengikuti program uji kompetensi yang masih kurang. Hasil temuan penelitian dari Nyoman, dkk (2014) yang menyatakan bahwa terdapat ketidaksesuaian antara tujaun dan pelaksanaan program sehingga menghasilkan produk yang bermutu rendah. Berdasarkan pada hasil temuan tersebut, maka dapat disimpulkan bahwa pada aspek evaluasi produk pada penyelenggaraan program Tempat Uji Kompetensi Teknik Otomotif di SMK Negeri 2 Salatiga masih belum sesuai.

Program Tempat Uji Kompetensi Teknik Otomotif SMK Negeri 2 Salatiga, didukung melalui sarana dan prasarana yang cukup memadahi. Fasilitas gedung, mesin peralatan dan sumber daya manusia yang baik menjadi alasan utama program tempat uji kompetensi untuk tetap memberikan pelayanan kepada masyarakat. Terlepas dari ditemukannya kendala yang muncul dalam pelaksanaan Program Tempat Uji Kompetensi Teknik Otomotif di SMK Negeri 2 Salatiga, namun demikian bahwa program ini sangat dibutuhkan oleh masyarakat.

Indentifikasi dan analisis kebutuhan, sampai dengan perencanaan program telah dilaksanakan oleh pengelola. Program Tempat Uji Kompetensi Teknik Otomotif di SMK Negeri 2 Salatiga telah berupaya untuk mewujudkan kegiatan manajemen pendidikan dalam penyelenggaraan program. Hal tersebut nampaknya selaras dengan pendapat Engkoswara (2010: 54) manajemen pendidikan sebagai sebuah kegiatan perencanaan, pengorganisasian, pengarahanan dan pengawasan usaha pendidikan untuk mencapai sebuah tujuan bersama. Oleh karena itu, adanya komponen pendukung dan kendala-kendala yang di hadapi dalam penyelenggaraan Program Tempat Uji Kompetensi Teknik Otomotif di SMK Negeri 2 Salatiga, maka perlu adanya sebuah rekomendasi terhadap keberlanjutan penyelenggaraan program tersebut.

Rekomendasi terhadap hasil evaluasi penyelenggaraan Program Tempat Uji Kompetensi Teknik Otomotif di SMK Negeri 2 Salatiga, selain didasarkan pada temuan hasil penelitian juga didasarkan pada kajian secara teoritis. Didalam rekomendasi terhadap kebijakan tindak lanjut dalam penyelenggaraan program khususnya melalui model evaluasi CIPP, terdapat empat klasifikasi yang dijadikan sebuah pedoman. Penyelenggaraan evaluasi dengan model CIPP, pada dasarnya memiliki empat pengaturan keputusan yaitu Homeostatic, Incremental, Neomobilistic dan Metamorphic (Rose \& Nyre, 1977). Lebih lanjut Rose \& Nyre menjelaskan bahwa keputusan homeostatic merupakan keputusan yang ditujukan untuk mempertahankan status quo. Keputusan Incremental merupakan keputusan yang diambil guna melakukan perbaikan-perbaikan terhadap suatu program.

Keputusan Neomobilistic keputusan yang diambil guna memecahkan permasalahan yang signifikan. Sedangkan keputusan Metamorphic keputusan yang diambil untuk melakukan perubahan yang menyeluruh terhadap suatu program. Merujuk pada klasifikasi model kebijakan tindak lanjut evaluasi program diatas, berdasarkan temuan penelitian bahwa Program Tempat Uji Kompetensi Teknik Otomotif di SMK Negeri 2 Salatiga telah berjalan dengan baik. Hal tersebut dapat ditunjukkan dengan dengan fasilitas dan sumber daya manusia yang cukup memadahi. Namun demikian dalam aspek proses ditemukan beberapa kendala yang dihadapi oleh pengelola. Melalui uraian diatas, dapat dipahami bahwa keputusan terhadap penyelenggaraan Program Tempat Uji Kompetensi Teknik Otomotif di SMK Negeri 2 Salatiga lebih mengarah pada keputusan Incremental. Hal tersebut nampaknya menjadi sebuah pertimbangan yang cukup penting, bahwa seyogyanya penyelenggaraan Program 
Tempat Uji Kompetensi Teknik Otomotif di SMK Negeri 2 Salatiga tetap dilanjutkan dengan disertai beberapa perbaikan.

\section{SIMPULAN DAN SARAN \\ Simpulan}

Evaluasi Penyelenggaraan Program Tempat Uji Kompetensi Teknik Otomotif di SMK Negeri 2 Salatiga sebagai berikut:

1. Penyelenggaraan Program Tempat Uji Kompetensi Teknik Otomotif di SMK Negeri 2 Salatiga pada aspekContext, telah didasarkan pada identifikasi kebutuhan, kebijakan dari pemerintah dan saran dari Dunia Usaha / Industri;

2. PenyelenggaraanProgramTempat Uji Kompetensi Teknik Otomotif di SMK Negeri 2 Salatiga pada aspek Input telah mencakup mekanisme penyelenggaraan program, sumber daya manusia, administratif, pembiayaan serta sarana dan prasarana yang sesuai;

3. PenyelenggaraanProgramTempat Uji Kompetensi Teknik Otomotif di SMK Negeri 2 Salatiga pada aspek Process masih belum sesuai dengan tujuan dan harapan, hal ini ditunjukkan dengan masih rendahnya minat siswa/luusan dan atau masyarakat yang memanfaatkan tempat uji kompetensi untuk melakukan uji kompetensi;

4. PenyelenggaraanProgramTempat Uji Kompetensi Teknik Otomotif di SMK Negeri 2 Salatiga pada aspek Product masih belum sesuai dengan apa yang diharapkan,hal tersebut ditunjukkan belumsemua dunia usaha dunia industri memberikan pengakuan terhadap sertifikasi uji kompetensi, bagi peserta uji yang dinyatakan Kompeten / lulus Uji kompetensi.

\section{Saran}

1. Program Tempat Uji Kompetensi Teknik Otomotif di SMK Negeri 2 Salatiga, perlu membuat terobosan-terobosan baru dalam rangka peningkatan kualitas program, Perlunya menjalin kerja sama dengan Dunia Industri terkait dengan penyelarasan terhadap kompetensi yang dibutuhkan di Dunia Industri;
2. Hasil penelitian ini menjadi pertimbangan bagi sekolah dalam rangka menyelenggarakan Tempat Uji Kompetensi Program Keahlian lainnya;

3. Dunia industri perlu melakukan suatu koordinasi dan komunikasi dengan pihak terkait perihal standart kompetensi kerja;

4. Dunia industri dapat memberikan peran sumbangsihnya dalam pengembangan tenaga kerja, khususnya pasca mengikuti kegiatan uji kompetensi.

\section{DAFTAR PUSTAKA}

Arikunto, Suharsini \& Abdul Jabar. C. Safruddin. 2009. Evaluasi Program Pendidikan: Pedoman Teoritis Praktis Bagi Mahasiswa dan Praktisi Pendidikan. Jakarta: BumiAksara.

Arikunto, Suharsini. 2010. Dasar-Dasar Evaluasi Pendidikan. Jakarta: Bumi Aksara.

Cai, Sheng Mao. Educational Feature of Singapore's Teaching Factory and Its Implication. Journal Institute of Vocational Education of Tongji University, Vol. 2, 2009, Shanghai.

Clare Rose \& Glenn F. Nyre. 1977. The Practice of Evaluation. Princetion: Education Testing Service.

Darmawan G. I Nyoman, Sumitro, Bambang, Djasmani, Sulton. Evaluasi Manajemen Teaching. Jurnal Manajemen Mutu Pendidikan, Vo. 2, No. 2, 2014, FKIP UNILA.

Engkoswara. 2010. Administrasi Pendidikan. Bandung: Alfabeta.

Ghozali, Ahmad \& Fuaduddin. 2003. Kepemimpinan Kepala Madrasah Yang Efektif (Modul 3). Jakarta: Pusdiklat Administrasi, BadanLibang Agama dan Diklat Keagamaan.

Hapsari, Melati Indri. Pengkajian Program Kursus dan Pelatihan Terkait dengan 
Jenis Keterampilan, Sertifikasi dan Penempatan Lulusan. Journal of Nonformal Education, Nomor. 2 Volume. 1, Tahun 2016, FIP Universitas Negeri Semarang.

Irawati, Y. D dan Sudira, Putu. Evaluasi Uji Kompetensi Siswa Keahlian Multimedia di SMK Se Kota Yogyakarta. Jurnal Pendidikan Vokasi, Vol. 4, Nomor. 3, November 2014, UNY.

Mustari, I Made Sudana, Eko Supraptono. Model Teaching Factory bagi Pembelajaran Merencana dan Menginstalasi Sistem Audio. Journal of Vocational and Career Education, Volume 2, Nomor 2, 2017, Hal: 96105.Universitas Negeri Semarang.

Mulyasa. E. 2003. Menjadi Guru Profesional. Cet. 11. Bandung: Remaja Rosdakarya

Nuryake, Fajaryati. Evaluasi Pelaksanaan Teaching Factory di SMK Surakarta. Junal Pendidikan Vokasi, Vol. 2, Nomor 3, November 2012, UNY.

Pan Wei Rong. Analysis of Teaching Factory Model of Nanyang Polytechnic. Journal ofGuangdong Communication Polytechnic. Vol. 4, 2009, Guangzhou.

Pidarta, Made. 2004. Manajemen Pendidikan Indonesia. Jakarta: Rineke Cipta.

Pratiwi, Monica. Ridwan. Waskito.Evaluasi Teaching Factory Model CIPP. Jurnal Imiah Pendidikan dan Pembelajaran, Volume 3, Nomor 3 Oktober 2019, Universitas Pendidikan Ganesha
Prihantoro, A.H. 2012. Administrasi, Organisasi dan Manajemen: Pendekatan Praktis danTeknik Mengelola Organisasi. Yogyakarta: Andi Offset

Santiyadnya, Nyoman. Evaluasi Program Pelaksanaan Uji Kompetensi Keahlian Produktif di SMK Negeri 3 Singaraja. Seminar Nasional Riset Inovatif III, Tahun 2015.

Setiawan, Andika. Widiyanti. Sunomo. Studi Pengelolaan Uji Kompetensi Keahlian Berlisensi Lembaga Sertifikasi Profesi Pada Jurusan Teknik Mesin di SMKN 1 Blitar. Jurnal Teknik Mesin Dan Pembelajaran, Volume 1, Nomor 1, Juni 2018, Halaman: 1 - 7, Universitas Negeri Malang. Diunduh dari https://journal.unesa.ac.id/index.php/jp eka, Senin 29 Juni 2020 jam 13.20

Sudjarwo. 2008. Evaluasi Kinerja Penyelenggaraan Pendidikan dan Pelatihan KepemimpinanTingkat IV Pada Balai Diklat Keagamaan Semarang. Semarang. Tesis: UniversitasDiponegoro.

Sugiyono. 2013. Metode Penelitian Kombinasi. Bandung: Alfabeta

Sujoko dan Bambang Ismanto, 2017, Evaluasi Peningkatan Pengalaman Belajar Program Unit Produksi Dan Jasa Bidang Keahlian Teknik Pemesinan SMK Negeri 2 Salatiga, Jurnal Pendidikan Ekonomi Manajemen Dan Keuangan Vol. 1 No. 1 Mei 2017

Wirawan. 2012. Evaluasi: Teori, Model, Standar, Aplikasi dan Profesi. Jakarta 